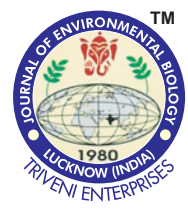

\title{
Enhancing production-extraction and antioxidant activity of astaxanthin from Haematococcus pluvialis
}

\section{Authors Info \\ S.M. Jung', J.Y. Jeon ${ }^{1}$, T.H. Park', J.H. Yoon', K.S. Lee ${ }^{2}$ and H.W. Shin $^{1 *}$ \\ ${ }^{1}$ Department of Life Science and Biotechnology, Soonchunhyang University, Asan City, Choongnam Do, 336-745, South Korea \\ ${ }^{2}$ Department of Sports Science, Soonchunhyang University, Asan City, Choongnam Do, 336-745, South Korea \\ *Corresponding Author Email : hwshin@sch.ac.kr \\ Edited by \\ Professor Chae Woo Ma \\ Reviewed by Dr. Han Seong Lee Professor Hari Datta Bhattarai}

\section{Abstract}

Aim: The growth of $H$. pluvialis by various extraction methods and was studied its growth, photosynthetic pigments and antioxidative ability under visible light and varying $\mathrm{pH}$ was compared.

Methodology: This study compared the growth of $H$. pluvialis under four different LED lights and three $\mathrm{pH}$ values, and demonstrated the astaxanthin content and antioxidant effects of them. The supercritical fluid chromatography and solvent extraction were conducted to compare the astaxanthin contents.

Results: The highest growth rate was observed under green LED light at all $\mathrm{pH}$ condition $(6,8,10)$. Under green LED, the correlation $\left(R^{2}\right)$ between cell counts and chlorophyll $a, b$ and total carotenoid was 0.9581 , 0.7652 and 0.9095 , respectively. The solvent extraction of astaxanthin from $H$. pluvialis was $137 \%$ higher than that of solid extract injection method using Super Fluid Chromatography.

Interpretation: This study will contribute in establishing the culture conditions to enhance the biomass and astaxanthin from $\mathrm{H}$. pluvialis.

Key words: Antioxidative activity, Astaxanthin, Haematococcus Pluvialis, Photosynthetic pigments

\section{Culture of green microalga (Haematococcus pluvialis)}

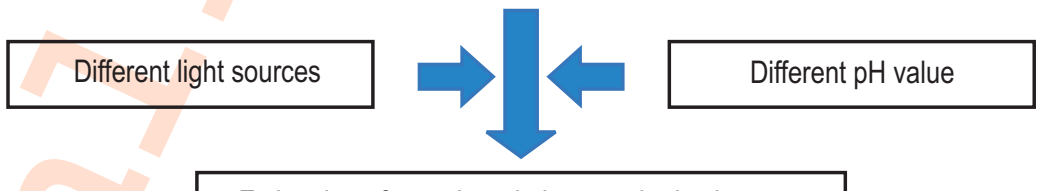

Estimation of growth and photosynthetic pigments

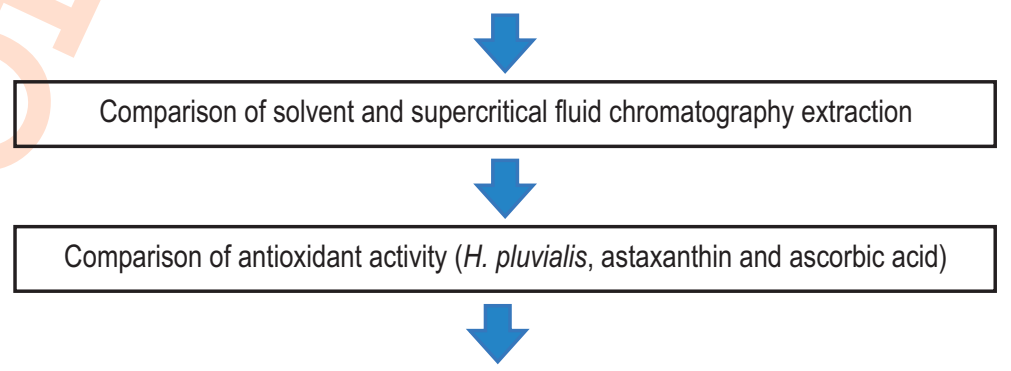

Solvent extraction was more affective than SFC and H. pluviais showed stronger antioxidant activity

How to cite : Jung, S.M., J.Y. Jeon, T.H. Park, J.H. Yoon, K.S. Lee and H.W. Shin: Enhancing production-extraction and antioxidant activity of astaxanthin from Haematococcus pluvialis. J. Environ. Biol., 40, 924-931 (2019). DOI : http://doi.org/10.22438/jeb/40/5(SI)/SI-14 


\section{Introduction}

Green microalga, Haematococcus pluvialis is well known to accumulate high amount of ketocarotenoid pigment, mainly astaxanthin. Chemically, astaxanthin is a combination of benzenoid rings and is a lipid-soluble keto-carotenoid rich in the natural environment. The carotenoid fraction of green vegetative cells consists of mostly lutein $(75-80 \%), \beta$-carotene (10-20\%) and others, including chlorophyll $a$ and $b$, primary carotenoids, violaxanthin, neoxanthin, lactucaxanthin and zeaxanthin (Renstrøm et al., 1981; Harker et al., 1996). At red stage, the total carotenoid content is markedly enhanced, and the characteristic primary carotenoid pattern of vegetative stage is replaced by secondary carotenoids, mainly astaxanthin (80-99\% of total carotenoids) (Harker et al., 1996; Dragos et al., 2010). The chemical name of astaxanthin is 3,3'-dihydroxy- $\beta, \beta^{\prime}$-carotene4,4'-dione which has antioxidant capacity. The ratio of carotenoids to chlorophylls is about 0.2 at green stage and increases 2-9 folds at red stage. The majority of astaxanthin is not deposited in its free form but it exists within the cell as fatty acid esters of astaxanthin, usually mono- or diesters of palmitic (16:0), oleic (18:1), or linoleic (18:2) acids. This type of modification is required for deposition of this highly polar molecule within nonpolar matrix of lipid droplets. Approximately, $70 \%$ monoesters, $25 \%$ diesters and only $5 \%$ of free ketocarotenoid are present in the mature "red" cells of $H$. pluvialis (Zhekisheva et al., 2002; Solovchenko, 2015). Under certain conditions, $H$. pluvialis accumulates up to $3-5 \%$ dried weight of astaxanthin (Han et al., 2013; Chekanov et al., 2014).

Therefore, photosynthetic unicellular $H$. pluvialis is always influenced by light source. One of the enhancing photosynthetical biomass, light emitting diodes (LEDs) are attracting attention as a light source for massive cultivation of microalgae and have an advantage in that the lifespan is 10 to 100 times longer than conventional fluorescent lamps and incandescent lamps. Studies on biocultures using LEDs was carried out first on land plants, and studies have shown that appropriate wavelengths are different depending on plant species and stages of development (Vanninen, 2010). Recently, researches have been conducted on the optimal wavelength verification and growth characteristics using LED culture system in microalgae and different photosynthetic wavelength range (Oh et al., 2008, Wallen and Geen, 1971).

Methods for extracting astaxanthin from $H$. pluvialis include the Supercritical fluid extraction and extraction with ethanol using ultrasound. Once the cell wall is disrupted and biomass is fully dried, the recovery of desired product is possible. Astaxanthin is a lipophilic compound and can be dissolved in solvents and oils. Astaxanthin can be extracted from $H$. pluvialis by different methods such as solvents, acids, edible oils, supercritical carbon dioxide $\left(\mathrm{SC}-\mathrm{CO}_{2}\right)$ as well as microwave and enzyme-assisted approaches. Among the recovery methods used solvent extraction and supercritical carbon dioxide $\left(\mathrm{SC}-\mathrm{CO}_{2}\right)$ extraction is considered as the most efficient, compatible, and widely used methods for astaxanthin extraction from $H$. pluvialis. Supercritical carbon dioxide $\left(\mathrm{SC}-\mathrm{CO}_{2}\right)$ extraction has been widely used for industrial applications due to many processing advantages. Due to low critical temperature of carbon dioxide, the $\mathrm{SC}-\mathrm{CO}_{2}$ system can be operated at moderate temperatures, preventing degradation of valuable substances (Machmudah et al., 2006). Several studies have reported experiments on supercritical $\mathrm{CO}_{2}$ extraction for the recovery of astaxanthin from $\mathrm{H}$. pluvialis. Considering astaxanthin quality as the most important criterion, supercritical $\mathrm{CO}_{2}$ extraction is the most favorable option. Supercritical $\mathrm{CO}_{2}$ provides shorter extraction time and limits the use of toxic organic solvents. In contrast to most solvents, $\mathrm{CO}_{2}$ is relatively cheap, chemically inert, non-toxic and stable (Zosel, 1974). Supercritical fluid extraction has also been tested with Haematococcus, to improve the extraction efficiency. For instance, supercritical carbon dioxide $\left(\mathrm{SC}-\mathrm{CO}_{2}\right.$ ) coupled with ethanol or vegetable oil as a cosolvent can further increase the extraction efficiency of astaxanthin (80-90\%) (Nobre et al., 2006; Krichnavaruk et al., 2008). There is an array of alternative approaches that can assist astaxanthin extraction from $H$. pluvialis such as solvents, acids, edible oils, enzymes or pressurized liquids (Sarada et al., 2006; Kang and Sim, 2008; Jaime et al., 2010; Dong et al., 2014).

However, there are many challenges for the development of large scale production of biomass and astaxanthin from $\mathrm{H}$. pluvialis. Due to these obstacles, the productivity can be hampered and in some cases failure of the production system can make the production process economically unsustainable. Various factors such as temperature, nutrients and $\mathrm{pH}$ should be supplied in optimal conditions for microalgae cultivation. In particular, the $\mathrm{pH}$ of the culture medium is involved in biomass regulation and photosynthesis, and microalgae (Azov and Goldman, 1982). To date, the effects of temperature, light intensity and $\mathrm{pH}$ have been studied in microalgae growth studies under various culture conditions, and studies using both visible wavelength and pH conditions are rare (Park et al., 2010). Furthermore, the antioxidant activity of extracts is mainly used by using ABTS (2,2-azino-bis-3-ethylbenzothiazoline-6-sulfonic acid) and 1,1-diphenyl-2-picrylhydrazyl (DPPH). Both methods are based on the principle that free radicals with hole electrons are combined with hydroxyl groups $(-\mathrm{OH})$ to inhibit the generation and reaction of radicals. In case of ABTS, the reaction appears as decolorization. DPPH appears as color and the color reaction is measured as absorbance (Lee et al., 2012).

In view of the above, in the present study, the growth rate, chlorophyll $a, b$ and total carotenoid contents of microalgae, $H$. pluvialis under varied $\mathrm{LED}$ and $\mathrm{pH}$ conditions was estimated. The extracts obtained by SFC and ethanol extraction were also compared to evaluate the quantity of astaxanthin and their 
antioxidant activity.

\section{Materials and Methods}

Haematococcus pluvialis was cultivated in Jaworski's medium for 20 days at $18^{\circ} \mathrm{C}$ and a light intensity of $37 \mu \mathrm{mol} \mathrm{m} \mathrm{m}^{-1}$ in a marine sample library (LIMS-PS-1354). The incubated $H$. pluvialis was inoculated in $30 \mathrm{ml}$ of Jaworski's medium into $3 \mathrm{ml}$ of $50 \mathrm{ml}$ Erlenmeyer flask. The incubation temperature was $20^{\circ} \mathrm{C}$ and the light intensity was fixed at $17 \mu \mathrm{mol} \mathrm{m} \mathrm{m}^{-2}$. The visible wavelengths was provided by white LED light (WLED, 400-800 $\mathrm{nm}$, JPL SS-light, Korea), blue LED light (BLED, 456 nm, KB3, SS-light, Korea), green LED light (GLED, 527 nm, KR3, SS-light, Korea) and red LED light (RLED, $625 \mathrm{~nm}$, KR4, SS-light, Korea), and the $\mathrm{pH}$ of the medium was adjusted to 6,8 , and 10 with $1 \mathrm{M}$ $\mathrm{HCl}$ and $1 \mathrm{M} \mathrm{NaOH}$, respectively. The growth of $H$. pluvialis was measured at 2-3 day interval after incubation and counted using an optical microscope (X200) (BX53, Olympus, Japan) and a hemodialysis counter (Neubauer Improved Bright-line, Marienfeld, Germany) simultaneously.

To determine chlorophyll $a, b$ and total carotenoid contents, $H$. pluvialis was transferred to a microtube in a $1 \mathrm{ml}$ aliquot and centrifuged at $14,000 \mathrm{rpm}$ for $10 \mathrm{~min}$. After removal of supernatant, homogenizer (7725 HOMG 5, IWAKI, Japan) was used and the cells were pulverized and extracted with $90 \%$ acetone at $4^{\circ} \mathrm{C}$ for $24 \mathrm{hrs}$ under dark conditions. After $24 \mathrm{hr}$ of extraction, the absorbance was measured at $470 \mathrm{~nm}, 645 \mathrm{~nm}$ and $662 \mathrm{~nm}$ using a spectrophotometer (UV-1601, Shimadzu, Japan) and calculated by the following formula given below Sukran et al., (1998).

Chl. $a=11.75$ Abs $662 \mathrm{~nm}-2.350$ Abs $645 \mathrm{~nm}$; Chl. $b=18.61$ Abs $645 \mathrm{~nm}-3.960$ Abs $662 \mathrm{~nm}$; Total carotenoid $=(1,000$ Abs $470 \mathrm{~nm}$ $-2.270 \mathrm{Chl} . \mathrm{a}-81.4 \mathrm{Chl}$. b) / 227

Preparative supercritical fluid chromatography, dry red dormant cells were used for the extraction of useful substances of $H$. pluvialis. Five gram of dry samples were extracted without preprocessing under the conditions of prep SFC (Burger SFC, Waters, USA) $\mathrm{CO}_{2}$ : $\mathrm{EtOH}=90: 10 \%$. Dry $5 \mathrm{~g}$ of $\mathrm{H}$. pluvialis dormant cells was dissolved in $100 \mathrm{ml}$ ethanol and extracted at 4 ${ }^{\circ} \mathrm{C}$ for 24 hrs under dark condition. The supernatant was collected by centrifugation at 8,000 rpm for 5 min (FLETA5, Hanil, Korea). To separate $H$. pluvialis extract by supercritical fluid chromatography, the astaxanthin standard reagent (Sigma Aldrich, USA) was dissolved in ethanol at concentrations of $1,000,500,250$ and $125 \mathrm{mg} \mathrm{l}^{-1}$, respectively. Analytical SFC (Nexera UC, Shimadzu, Japan) was used to analyze the prepackaged SFC extract, ethanol extract and concentration standard reagents. Amino column was used according to the results of preliminary experiments. Ethanol was used as mobile phase solvent and measured in the presence of $\mathrm{CO}_{2}: \mathrm{EtOH}=90$ : $10 \%$ at $480 \mathrm{~nm}$ following the method of Kang et al. (2006).
Astaxanthin content was calculated from calibration curve of standard value.

The modified method of Helle et al. (2004) was used to compare the antioxidant capacity of $H$. pluvialis extract and astaxanthin. $H$. pluvialis extract was diluted with DMSO to 0.008 , $0.004,0.002$ and $0.001 \mathrm{mg} \mathrm{l}^{-1}$ and astaxanthin was $0.8,0.4,0.2$, 0.1 and $0.05 \mathrm{mg} \mathrm{l}^{-1}$. Ascorbic acid used as a control group was diluted to $20,10,5$ and $2.5 \mathrm{mg} \mathrm{I}^{-1}$ to prepare $1 \mathrm{ml}$ of each sample. DPPH (2,2-diphenyl-1-picrylhydrazyl) was dissolved in ethanol at $0.15 \mathrm{mM}$ to prepare a DPPH solution. After preparing the sample and DPPH solution, the DPPH solution was mixed with diluted samples in 1:1 ratio, and the color was developed for $30 \mathrm{~min}$ under dark condition. The absorbance value was measured at $517 \mathrm{~nm}$ using a spectrophotometer (UV-1601, Shimadzu, Japan) to calculate the scavenging activity (\%).

$$
\text { Scavenging activity }(\%)=\frac{A B S \text { con. }- \text { ABS sam. }}{A B S \text { con. }} \times 100
$$

The results of $H$. pluvialis growth according to visible wavelength and $\mathrm{pH}$ were analyzed using SPSS (ver. 17.0) Oneway ANOVA, followed by post-hoc analysis using Tukey's test and the correlation between cell counts and chlorophyll $a, b$ and carotenoid content was analyzed.

\section{Results and Discussion}

This study provides an insight about the latest scientific and technological advancements in target aspects of astaxanthin-producing microalga, $H$. pluvialis such as enhancing biomass production, downstream processing and antioxidant activity. $H$. pluvialis has attracted attention as a microalgae that has high antioxidant content of astaxanthin of $1.5 \sim 3 \%$, higher than other raw materials, and easy to cultivate and manage (Lorenz and Cysewski, 2000). H. pluvialis is largely divided into nutritional cells that swim with flagellum and dormant cystic cells that are converted by external stimuli. During the conversion stage, cells turn red and accumulate astaxanthin (Kang et al., 2006). Although antioxidant activity of astaxanthin has been reported to be 550 times higher than a-tocopherol, chemically synthesized components have low stability in the body. Recently, various extraction methods have been studied to enhance astaxanthin extraction efficiency from natural raw material, $H$. pluvialis (Xiaoyan et al., 2016). Although studies have been conducted to increase the extraction yield of astaxanthin and to increase astaxanthin content in $\mathrm{H}$. pluvialis, studies to increase the biomass of $H$. pluvialis as a raw material have been conducted (Oraosa et al., 2005).

The growth of $H$. pluvialis according to visible wavelength was highest in green LED light as compared to white LED light (380 $780 \mathrm{~nm}$ ), blue LED light (456 nm), green LED light (527 nm) and red RLED light ( $625 \mathrm{~nm})$, respectively. The number of cells in 
white light $(380 \sim 780 \mathrm{~nm})$ was highest at $3.6 \times 10^{4} \pm 1 \times 10^{3}$ cells $\mathrm{ml}^{-1}$ at $\mathrm{pH} 6$. In blue light $(456 \mathrm{~nm})$, the highest value was $2.4 \times 10^{4}$ $\pm 5 \times 10^{2}$ cells $\mathrm{ml}^{-1}$ at $\mathrm{pH} 6$ and there was no difference in the number of cells between $\mathrm{pH} 8$ and 10 . In green light $(527 \mathrm{~nm})$, the highest concentration was $9 \times 10^{4} \pm 1 \times 10^{3}$ cells $\mathrm{ml}^{-1}$ at $\mathrm{pH} 10$. In red light $(625 \mathrm{~nm})$ the number of cell was highest of $\mathrm{pH} 6\left(4.6 \times 10^{4}\right.$ $\pm 1 \times 10^{3}$ cells $\mathrm{ml}^{-1}$ ) number of cells at $\mathrm{pH} 8$ and 10 was not different (Table 1). Overall, their growth rates were higher for green and white light than for blue and red, but $\mathrm{pH}$ values were different for each light source.

The maturation stage of matured cells or maturation of non-nutrient cells was fastest in blue light and red light on the third

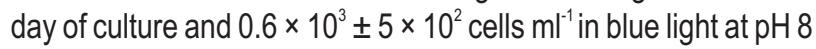
and 10 , and $11 \%$ and 3 , respectively, of the total number of cells in the corresponding conditions of each wavelength and $\mathrm{pH}$, including nutritive cells. Matured cells on 15th day of culture showed the highest quantity of $1.1 \times 10^{4} \pm 5 \times 10^{2}{\text { cells } \mathrm{I}^{-1}}^{-1}$ at $\mathrm{pH}$ 10 in the case of white light and $41 \pm 0.76 \%$ of the total cell number and not observed at $\mathrm{pH} 6$. In blue light, it was $1 \times 10^{4} \pm 1 \times$ $10^{3}$ cells ml ${ }^{-1}$ at $\mathrm{pH} 6$ on day 15 and was highest $(40 \pm 4.3 \%$ of total cells). In red light, it was $8 \times 10^{3} \pm 2 \times 10^{3}$ cells $\mathrm{ml}^{-1}$ at $\mathrm{pH} 8$ and highest was $41 \pm 11.9 \%$ of total cells (Table 1 ). The maturation was accelerated at $\mathrm{pH} 10$ of white light and $\mathrm{pH} 6$ of blue.

Tomohisa et al. (2004) showed that blue light enhanced the astaxanthin content of $H$. pluvialis, which was the highest production rate. After transformation into dormant cells on third day of culture on the nature of $H$. pluvialis, growth rate was lower than other wavelengths (Makio et al., 1997). The growth of $H$. pluvialis showed a difference of $3.66 \%$ depending on the wavelength and $2.1 \%$ depending on $\mathrm{pH}$, indicating that the visible wavelength is a physical factor affecting $H$. pluvialis growth over $\mathrm{pH}$.

The highest $\mathrm{Chl}$ a was $0.56 \mathrm{\mu g} \mathrm{ml}^{-1}$ in green light at $\mathrm{pH} 6$ on 15th day, followed by blue light, white light and red light (Table 2). At pH 8, the green light the highest $\mathrm{Chl}$ a nature of $0.44 \mathrm{\mu g} \mathrm{ml}^{-1}$. $\mathrm{At} \mathrm{pH} 10$ also the highest $\mathrm{Chl}$ a value was seen in green light (0.93 $\mu \mathrm{g} \mathrm{ml}^{-1}$ ) followed by white light, red light and blue light (Table 2). In case of blue light, after 12 days of culture at all $\mathrm{pH}$ conditions, chlorophyll a decreased.

In case of white light, the highest value of chl a was 0.32 $\mu \mathrm{g} \mathrm{ml}^{-1}$ at $\mathrm{pH} 10$. In blue light, the highest chl a was at $\mathrm{pH} 10(0.17$ $\left.\mu \mathrm{g} \mathrm{ml}^{-1}\right)$, but chlorophyll a content decreased after 12 days. In green light, the highest value was $0.93 \mu \mathrm{g} \mathrm{ml}^{-1}$ at $\mathrm{pH} 10$. In red light, the highest chl a was at pH $6\left(0.37 \pm 0.004 \mu \mathrm{g} \mathrm{ml}^{-1}\right)$ (Table 2).

As a result of measuring the content of chlorophyll $b$ (chl. b) according to the visible wavelength, the highest value was found at the $\mathrm{pH}$ of 6 on the 15th day of the measurement, as 0.39 $\mu \mathrm{g} \mathrm{ml}^{-1}$, in the green light and the blue, white, but there was no difference between blue and white. At $\mathrm{pH} 8$, green light was the highest at $0.18 \mathrm{\mu g} \mathrm{ml}^{-1}$, and the wavelengths except green light were not different (Table 3). $\mathrm{pH} 10$ was also the highest at $0.36 \mu \mathrm{g}$ $\mathrm{ml}^{-1}$, in green light and no difference between the remaining wavelengths. The content of chlorophyll $b$ (chl. $b$ ) according to $\mathrm{pH}$ was $0.23 \mathrm{\mu g} \mathrm{ml}^{-1}$ in the group cultured at $\mathrm{pH} 6$ in white light, followed by $\mathrm{pH} 10$, In the case of blue light, at $\mathrm{pH} 6$ was the highest at $0.26 \mathrm{ug} \mathrm{ml}^{-1}$, and no difference was observed between $\mathrm{pH} 8$ and 10. In the case of green light, $\mathrm{pH} 6$ was highest at $0.39 \mathrm{\mu g} \mathrm{ml}^{-1}$, and

Table 1 : Comparison of cell number (cells $\mathrm{ml}^{-1}$ ) of Haematococcus pluvialis different $\mathrm{pH}$ values $(6,8$ and 10)

\begin{tabular}{|c|c|c|c|c|c|}
\hline Day & $\mathrm{pH}$ & $380 \sim 780 \mathrm{~nm}$ & $456 \mathrm{~nm}$ & $527 \mathrm{~nm}$ & $625 \mathrm{~nm}$ \\
\hline \multirow[t]{3}{*}{0} & 6 & $2.6 \times 10^{3} \pm 5.7 \times 10^{2}$ & $2.6 \times 10^{3} \pm 5.7 \times 10^{2}$ & $2.6 \times 10^{3} \pm 5.7 \times 10^{2}$ & $2.6 \times 10^{3} \pm 5.7 \times 10^{2}$ \\
\hline & 8 & $2.6 \times 10^{3} \pm 5.7 \times 10^{2}$ & $2.6 \times 10^{3} \pm 5.7 \times 10^{2}$ & $2.6 \times 10^{3} \pm 5.7 \times 10^{2}$ & $2.6 \times 10^{3} \pm 5.7 \times 10^{2}$ \\
\hline & 10 & $2.6 \times 10^{3} \pm 5.7 \times 10^{2}$ & $2.6 \times 10^{3} \pm 5.7 \times 10^{2}$ & $2.6 \times 10^{3} \pm 5.7 \times 10^{2}$ & $2.6 \times 10^{3} \pm 5.7 \times 10^{2}$ \\
\hline \multirow[t]{3}{*}{3} & 6 & $1.9 \times 10^{4} \pm 5.7 \times 10^{2 b}$ & $1 \times 10^{4} \pm 1 \times 10^{3 \mathrm{ab}}$ & $1.2 \times 10^{4} \pm 5.7 \times 10^{2 b}$ & $5.3 \times 10^{3} \pm 5.7 \times 10^{2 \mathrm{NS}}$ \\
\hline & 8 & $1.6 \times 10^{4} \pm 1 \times 10^{3 \mathrm{ab}}$ & $4.6 \times 10^{3} \pm 5 \times 10^{2 a}$ & $3.3 \times 10^{3} \pm 5.7 \times 10^{2 a}$ & $6 \times 10^{3} \pm 1 \times 10^{3 \mathrm{NS}}$ \\
\hline & 10 & $1.2 \times 10^{4} \pm 5.7 \times 10^{2 a}$ & $1.5 \times 10^{4} \pm 2.5 \times 10^{3 b}$ & $4.6 \times 10^{3} \pm 1.1 \times 10^{3 a}$ & $5.3 \times 10^{3} \pm 5.7 \times 10^{2 \mathrm{NS}}$ \\
\hline \multirow[t]{3}{*}{6} & 6 & $2.5 \times 10^{4} \pm 5.7 \times 10^{2 b}$ & $1.7 \times 10^{4} \pm 5 \times 10^{2 b}$ & $2.5 \times 10^{4} \pm 5.7 \times 10^{2 \mathrm{a}}$ & $2.3 \times 10^{4} \pm 1.1 \times 10^{3 b}$ \\
\hline & 8 & $1.7 \times 10^{4} \pm 5 \times 10^{2 a}$ & $6.6 \times 10^{3} \pm 5 \times 10^{2 a}$ & $1.8 \times 10^{4} \pm 1.5 \times 10^{3 b}$ & $1.2 \times 10^{4} \pm 1.1 \times 10^{3 a}$ \\
\hline & 10 & $1.7 \times 10^{4} \pm 5.7 \times 10^{2 \mathrm{a}}$ & $1.6 \times 10^{4} \pm 1 \times 10^{3 b}$ & $1.7 \times 10^{4} \pm 5.7 \times 10^{2 b}$ & $1.6 \times 10^{4} \pm 5.7 \times 10^{2 a}$ \\
\hline \multirow[t]{3}{*}{9} & 6 & $2.8 \times 10^{4 b}$ & $1.8 \times 10^{4} \pm 5 \times 10^{2 b}$ & $3.1 \times 10^{4} \pm 1.1 \times 10^{3 b}$ & $3.3 \times 10^{4} \pm 5.7 \times 10^{2 c}$ \\
\hline & 8 & $1.8 \times 10^{4} \pm 1 \times 10^{3 a}$ & $7.3 \times 10^{3} \pm 5 \times 10^{2 a}$ & $2.2 \times 10^{4} \pm 1 \times 10^{3 a}$ & $1.4 \times 10^{4} \pm 2 \times 10^{3 \mathrm{a}}$ \\
\hline & 10 & $1.8 \times 10^{4} \pm 1 \times 10^{3 a}$ & $1.6 \times 10^{4} \pm 2 \times 10^{3 b}$ & $3.2 \times 10^{4} \pm 2.5 \times 10^{3 b}$ & $2.1 \times 10^{4} \pm 5.7 \times 10^{2 b}$ \\
\hline \multirow[t]{3}{*}{12} & 6 & $3.5 \times 10^{4} \pm 2 \times 10^{3 b}$ & $2.3 \times 10^{4} \pm 1.5 \times 10^{3 b}$ & $4.8 \times 10^{4} \pm 3 \times 10^{3 b}$ & $4.5 \times 10^{4} \pm 5.7 \times 10^{2 \mathrm{c}}$ \\
\hline & 8 & $1.9 \times 10^{4} \pm 1.1 \times 10^{3 a}$ & $8.6 \times 10^{3} \pm 5.7 \times 10^{2 a}$ & $3.5 \times 10^{4} \pm 2.5 \times 10^{3 a}$ & $1.7 \times 10^{3} \pm 1.1 \times 10^{3 \mathrm{a}}$ \\
\hline & 10 & $2.3 \times 10^{4} \pm 3 \times 10^{3 a}$ & $1.8 \times 10^{4} \pm 1 \times 10^{3 b}$ & $7.6 \times 10^{4} \pm 1.5 \times 10^{3 c}$ & $2.3 \times 10^{4} \pm 5.7 \times 10^{2 b}$ \\
\hline \multirow[t]{3}{*}{15} & 6 & $3.6 \times 10^{4} \pm 1 \times 10^{3 c}$ & $2.4 \times 10^{4} \pm 5 \times 10^{2 a}$ & $5.6 \times 10^{4} \pm 1.1 \times 10^{3 b}$ & $4.6 \times 10^{4} \pm 5.7 \times 10^{2 b}$ \\
\hline & 8 & $2 \times 10^{4} \pm 1 \times 10^{3 a}$ & $9.3 \times 10^{3} \pm 1.1 \times 10^{3 a}$ & $3.9 \times 10^{4} \pm 1.5 \times 10^{3 a}$ & $2 \times 10^{4} \pm 1 \times 10^{3 \mathrm{a}}$ \\
\hline & 10 & $2.8 \times 10^{4} \pm 5.7 \times 10^{2 b}$ & $1.9 \times 10^{4} \pm 1.1 \times 10^{3 b}$ & $9 \times 10^{4} \pm 1 \times 10^{3 c}$ & $2.4 \times 10^{4} \pm 1 \times 10^{3 a}$ \\
\hline
\end{tabular}

Values are mean $\pm S D$; NS: Not significant; $p<0.05$, One-wayANOVA, Tukey-HSD 
Table 2: Comparison of chlorophyll a contents $\left(\mu_{\mathrm{g} \mathrm{mg}}{ }^{-1}\right)$ of Haematococcus pluvialis at different $\mathrm{pH}$ values $(6,8$ and 10$)$

\begin{tabular}{|c|c|c|c|c|c|}
\hline Day & $\mathrm{pH}$ & $380 \sim 780 \mathrm{~nm}$ & $456 \mathrm{~nm}$ & $527 \mathrm{~nm}$ & $625 \mathrm{~nm}$ \\
\hline \multirow[t]{3}{*}{0} & 6 & 0.044 & 0.044 & 0.044 & 0.044 \\
\hline & 8 & 0.044 & 0.044 & 0.044 & 0.044 \\
\hline & 10 & 0.044 & 0.044 & 0.044 & 0.044 \\
\hline \multirow[t]{3}{*}{3} & 6 & $0.133 \pm 0.003^{a}$ & $0.446^{b}$ & $0.097 \pm 0.002^{a}$ & $0.062^{b}$ \\
\hline & 8 & $0.176^{b}$ & $0.05 \pm 0.0006^{a}$ & $0.077^{\mathrm{a}}$ & $0.047 \pm 0.001^{a}$ \\
\hline & 10 & $0.177 \pm 0.0007^{b}$ & $0.136 \pm 0.003^{\mathrm{ab}}$ & $0.086 \pm 0.003^{b}$ & $0.088 \pm 0.0006^{\circ}$ \\
\hline \multirow[t]{3}{*}{6} & 6 & $0.186 \pm 0.004^{a}$ & $0.13 \pm 0.006^{b}$ & $0.249 \pm 0.014^{b}$ & $0.142 \pm 0.013^{b}$ \\
\hline & 8 & $0.201 \pm 0.004^{\mathrm{ab}}$ & $0.083 \pm 0.005^{\mathrm{a}}$ & $0.144 \pm 0.011^{a}$ & $0.05 \pm 0.005^{\mathrm{a}}$ \\
\hline & 10 & $0.214 \pm 0.002^{b}$ & $0.139 \pm 0.003^{c}$ & $0.358 \pm 0.018^{c}$ & $0.129 \pm 0.003^{b}$ \\
\hline \multirow[t]{3}{*}{9} & 6 & $0.195 \pm 0.003^{\mathrm{a}}$ & $0.116 \pm 0.01^{b}$ & $0.338 \pm 0 . .01^{b}$ & $0.258 \pm 0.011^{c}$ \\
\hline & 8 & $0.234 \pm 0.002^{b}$ & $0.154 \pm 0.05^{\mathrm{a}}$ & $0.217 \pm 0.01^{\mathrm{a}}$ & $0.078 \pm 0.004^{a}$ \\
\hline & 10 & $0.223 \pm 0.003^{b}$ & $0.258 \pm 0.011^{c}$ & $0.49 \pm 0.008^{c}$ & $0.147 \pm 0.003^{b}$ \\
\hline \multirow[t]{3}{*}{12} & 6 & $0.206 \pm 0.006^{a}$ & $0.276 \pm 0.006^{b}$ & $0.491 \pm 0.005^{b}$ & $0.354 \pm 0.006^{c}$ \\
\hline & 8 & $0.244 \pm 0.008^{b}$ & $0.164 \pm 0.006^{\mathrm{a}}$ & $0.352 \pm 0.009^{a}$ & $0.122 \pm 0.002^{\mathrm{a}}$ \\
\hline & 10 & $0.32 \pm 0.004^{c}$ & $0.169 \pm 0.006^{c}$ & $0.785 \pm 0.011^{\circ}$ & $0.176^{b}$ \\
\hline \multirow[t]{3}{*}{15} & 6 & $0.225 \pm 0.006^{a}$ & $0.177 \pm 0.006^{b}$ & $0.56 \pm 0.008^{b}$ & $0.372 \pm 0.004^{c}$ \\
\hline & 8 & $0.265 \pm 0.005^{b}$ & $0.122 \pm 0.006^{\mathrm{a}}$ & $0.445 \pm 0.008^{a}$ & $0.137 \pm 0.003^{a}$ \\
\hline & 10 & $0.326 \pm 0.005^{c}$ & $0.145 \pm 0.006^{c}$ & $0.932 \pm 0.01^{c}$ & $0.184 \pm 0.012^{b}$ \\
\hline
\end{tabular}

Values are mean $\pm S D$; NS: Not significant; $p<0.05$, One-way ANOVA, Tukey-HSD

Table 3 : Comparison of chlorophyll $b$ contents $\left(\mu \mathrm{g} \mathrm{mg}^{-1}\right)$ of Haematococcus pluvialis by different $\mathrm{pH}$ values $(6,8$ and 10$)$

\begin{tabular}{|c|c|c|c|c|c|}
\hline Day & $\mathrm{pH}$ & $380 \sim 780 \mathrm{~nm}$ & $456 \mathrm{~nm}$ & $527 \mathrm{~nm}$ & $625 \mathrm{~nm}$ \\
\hline \multirow[t]{3}{*}{0} & 6 & 0.002 & 0.002 & 0.002 & 0.002 \\
\hline & 8 & 0.002 & 0.002 & 0.002 & 0.002 \\
\hline & 10 & 0.002 & 0.002 & 0.002 & 0.002 \\
\hline \multirow[t]{3}{*}{3} & 6 & $0.038 \pm 0.004^{\mathrm{NS}}$ & $0.002^{\mathrm{NS}}$ & $0.032 \pm 0.019^{\mathrm{NS}}$ & $0.006^{\mathrm{NS}}$ \\
\hline & 8 & $0.029^{\mathrm{NS}}$ & $0.042 \pm 0.005^{\mathrm{NS}}$ & $0.009^{\mathrm{NS}}$ & $0.012 \pm 0.005^{\mathrm{NS}}$ \\
\hline & 10 & $0.017 \pm 0.005^{\mathrm{NS}}$ & $0.019 \pm 0.004^{\mathrm{NS}}$ & $0.053 \pm 0.004^{\mathrm{NS}}$ & $0.011 \pm 0.005^{\mathrm{NS}}$ \\
\hline \multirow[t]{3}{*}{6} & 6 & $0.067 \pm 0.017^{\mathrm{NS}}$ & $0.039 \pm 0.007^{\mathrm{NS}}$ & $0.07 \pm 0.008^{a}$ & $0.058 \pm 0.013^{\mathrm{NS}}$ \\
\hline & 8 & $0.039 \pm 0.01^{\mathrm{NS}}$ & $0.048 \pm 0.005^{\mathrm{NS}}$ & $0.04 \pm 0.005^{\mathrm{a}}$ & $0.048 \pm 0.005^{\mathrm{NS}}$ \\
\hline & 10 & $0.052 \pm 0.008^{\mathrm{NS}}$ & $0.024 \pm 0.001^{\mathrm{NS}}$ & $0.217 \pm 0.014^{b}$ & $0.015 \pm 0.004^{\mathrm{NS}}$ \\
\hline \multirow[t]{3}{*}{9} & 6 & $0.088 \pm 0.004^{b}$ & $0.046 \pm 0.01^{\mathrm{NS}}$ & $0.081 \pm 0.012^{\mathrm{a}}$ & $0.061 \pm 0.001^{b}$ \\
\hline & 8 & $0.045 \pm 0.008^{a}$ & $0.055 \pm 0.007^{\mathrm{NS}}$ & $0.057 \pm 0.007^{a}$ & $0.062 \pm 0.01^{\mathrm{b}}$ \\
\hline & 10 & $0.073 \pm 0.004^{a}$ & $0.025 \pm 0.003^{\mathrm{NS}}$ & $0.303 \pm 0.024^{b}$ & $0.021 \pm 0.001^{a}$ \\
\hline \multirow[t]{3}{*}{12} & 6 & $0.203 \pm 0.009^{b}$ & $0.096 \pm 0.004^{c}$ & $0.321 \pm 0.008^{a}$ & $0.07 \pm 0.003^{b}$ \\
\hline & 8 & $0.054 \pm 0.013^{a}$ & $0.063 \pm 0.009^{b}$ & $0.148 \pm 0.006^{b}$ & $0.071 \pm 0.009^{b}$ \\
\hline & 10 & $0.105 \pm 0.013^{\mathrm{a}}$ & $0.026 \pm 0.003^{a}$ & $0.341 \pm 0.011^{\mathrm{a}}$ & $0.029^{a}$ \\
\hline \multirow[t]{3}{*}{15} & 6 & $0.232 \pm 0.009^{b}$ & $0.261 \pm 0.009^{b}$ & $0.398 \pm 0.007^{b}$ & $0.135 \pm 0.015^{b}$ \\
\hline & 8 & $0.064 \pm 0.012^{\mathrm{a}}$ & $0.071 \pm 0.016^{\mathrm{a}}$ & $0.182 \pm 0.014^{\mathrm{a}}$ & $0.131 \pm 0.009^{a b}$ \\
\hline & 10 & $0.115 \pm 0.015^{\mathrm{a}}$ & $0.063 \pm 0.005^{\mathrm{a}}$ & $0.368 \pm 0.021^{b}$ & $0.05 \pm 0.021^{\mathrm{a}}$ \\
\hline
\end{tabular}

Values are mean $\pm S D$; NS: Not significant; $p<0.05$, One-way ANOVA, Tukey-HSD

$\mathrm{pH} 8$ was the lowest at $0.18 \mu \mathrm{g} \mathrm{ml}^{-1}$ (Table 4$)$. In red light, there was no difference between $\mathrm{pH} 8$ and 6 and $\mathrm{pH} 10$ was the lowest $(0.05$ $\mu \mathrm{g} \mathrm{ml}^{-1}$ ) (Table 3).

The total carotenoid content at $\mathrm{pH} 6$ was highest $(68.58$ $\mu \mathrm{g} \mathrm{ml}{ }^{-1}$ ) and lowest at $49.5 \mathrm{mg} \mathrm{ml}^{-1}$, with no difference between white and red light. At pH 8, white light produced the carotenoid highest $\left(60.7 \mathrm{~g} \mathrm{ml}^{-1}\right)$, whereas in blue light it was lowest (34.36 $\mu \mathrm{g} \mathrm{ml}^{-1}$ ), and there was no difference between green and red light. At $\mathrm{pH} \mathrm{10,} \mathrm{green} \mathrm{light} \mathrm{showed} \mathrm{the} \mathrm{highest} \mathrm{carotenoid} \mathrm{content}$ (98.08 $\mathrm{Mg} \mathrm{ml}^{-1}$ ), followed by white light, red light and blue light (Table 4).

The total carotenoid content, in white light did not vary at different $\mathrm{pH}$. In blue light, at $\mathrm{pH} 6$ total carotenoid was highest (49.504 $\mathrm{Mg} \mathrm{ml}^{-1}$ ) whereas at $\mathrm{pH} 8$ and 10 it was not different. In 
Table 4: Comparison of total carotenoid content $\left(\mu \mathrm{g} \mathrm{mg}^{-1}\right)$ of Haematococcus pluvialis at different $\mathrm{pH}$ values $(6,8$ and 10$)$

\begin{tabular}{|c|c|c|c|c|c|}
\hline Day & $\mathrm{pH}$ & $380 \sim 780 \mathrm{~nm}$ & $456 \mathrm{~nm}$ & $527 \mathrm{~nm}$ & $625 \mathrm{~nm}$ \\
\hline \multirow[t]{3}{*}{0} & 6 & $3.56 \pm 0.57$ & $3.56 \pm 0.57$ & $3.56 \pm 0.57$ & $3.56 \pm 0.57$ \\
\hline & 8 & $3.56 \pm 0.57$ & $3.56 \pm 0.57$ & $3.56 \pm 0.57$ & $3.56 \pm 0.57$ \\
\hline & 10 & $3.56 \pm 0.57$ & $3.56 \pm 0.57$ & $3.56 \pm 0.57$ & $3.56 \pm 0.57$ \\
\hline \multirow[t]{3}{*}{3} & 6 & $12.01 \pm 0.56^{\mathrm{a}}$ & $4.23 \pm 1^{\mathrm{a}}$ & $16.1 \pm 0.57^{b}$ & $2.92^{\mathrm{a}}$ \\
\hline & 8 & $18.25 \pm 0.57^{\circ}$ & $11.86^{b}$ & $10.82^{a}$ & $7.25 \pm 0.57^{b}$ \\
\hline & 10 & $15.25 \pm 0.57^{b}$ & $13.35 \pm 0.56^{c}$ & $16.44 \pm 0.57^{\mathrm{b}}$ & $3.46 \pm 1.15^{\mathrm{a}}$ \\
\hline \multirow[t]{3}{*}{6} & 6 & $20.88 \pm 3.06^{\mathrm{a}}$ & $18.69 \pm 1.01^{\mathrm{a}}$ & $35.4 \pm 1.75^{b}$ & $24.32 \pm 2.03^{b}$ \\
\hline & 8 & $31.19 \pm 1.14^{b}$ & $22.12 \pm 1.5^{b}$ & $17.98 \pm 2.1^{\mathrm{a}}$ & $13.53 \pm 2.52^{\mathrm{a}}$ \\
\hline & 10 & $29.49 \pm 1.72^{b}$ & $22 \pm 1.52^{\mathrm{ab}}$ & $44.77 \pm 4.19^{\mathrm{C}}$ & $15.03 \pm 1.52^{\mathrm{a}}$ \\
\hline \multirow[t]{3}{*}{9} & 6 & $31.19 \pm 0.56^{\mathrm{a}}$ & $27.24 \pm 1.5^{\mathrm{NS}}$ & $42.86 \pm 2.09^{b}$ & $31.05 \pm 2.03^{b}$ \\
\hline & 8 & $39.11 \pm 1.13^{b}$ & $27.38 \pm 1.56^{\mathrm{NS}}$ & $24.48 \pm 2.65^{\mathrm{a}}$ & $18.13 \pm 0.57^{\mathrm{a}}$ \\
\hline & 10 & $31.13 \pm 1.16^{\mathrm{a}}$ & $27.3 \pm 1.53^{\mathrm{NS}}$ & $62.44 \pm 3.07^{\circ}$ & $19.32 \pm 0.57^{\mathrm{a}}$ \\
\hline \multirow[t]{3}{*}{12} & 6 & $57.12 \pm 0.56^{b}$ & $42 \pm 0.6^{b}$ & $61.76 \pm 0.03^{b}$ & $47.16 \pm 0.02^{c}$ \\
\hline & 8 & $57.09 \pm 0.59^{b}$ & $33.27 \pm 1.18^{a}$ & $38.14 \pm 0.96^{\mathrm{a}}$ & $28.69 \pm 0.01^{\mathrm{a}}$ \\
\hline & 10 & $50.9 \pm 1.12^{a}$ & $32.6 \pm 0.02^{a}$ & $86.76 \pm 0.51^{\circ}$ & $32.58^{b}$ \\
\hline \multirow[t]{3}{*}{15} & 6 & $61.07 \pm 2.05^{\mathrm{NS}}$ & $49.5 \pm 2.02^{b}$ & $68.58 \pm 1.03^{b}$ & $60.77 \pm 2.07^{b}$ \\
\hline & 8 & $60.7 \pm 1.52^{\mathrm{NS}}$ & $34.36 \pm 1.49^{a}$ & $48.25 \pm 1.16^{\mathrm{a}}$ & $47.3 \pm 11.7^{\mathrm{a}}$ \\
\hline & 10 & $59.55 \pm 1.53^{\mathrm{NS}}$ & $33.64 \pm 1.05^{\mathrm{a}}$ & $98.08 \pm 0.58^{\circ}$ & $37.89 \pm 1.56^{\mathrm{a}}$ \\
\hline
\end{tabular}

Values are mean $\pm S D$; NS: Not significant; $p<0.05$, One-way ANOVA, Tukey-HSD

Table 5 : Comparison of SFC and ethanol extraction methods of astaxanthin from Haematococcus pluvialis

\begin{tabular}{llll}
\hline Sample & Time $(\min )$ & Area & Content $\left(\mathbf{m g ~ g}^{-1}\right)$ \\
\hline SFC extraction & 6.403 & 5,066 & 0.53 \\
EtOH extraction & 6.678 & 18,603 & 1.26 \\
\hline
\end{tabular}

Table 6 : Comparison of DPPH radical activity $\left(\mathrm{mg} \mathrm{l}^{-1}\right)$ of Haematococcus pluvialis, astaxanthin and ascorbic acid

\begin{tabular}{ll}
\hline Sample & I $_{50}$ \\
\hline H. pluvialis & 48.09 \\
astaxanthin & 0.12 \\
ascorbic acid & 14 \\
\hline
\end{tabular}

case of green light, the highest value $\left(98.08 \mathrm{\mu g} \mathrm{ml}^{-1}\right)$ was found at $\mathrm{pH} 10$, followed by $\mathrm{pH} 6$ and 8 . In red light at $\mathrm{pH} 6$, total carotenoid content $\left(60.77 \mathrm{\mu g} \mathrm{ml}^{-1}\right)$ was highest, however, there was no difference between pH 8 and 10 (Table 4). At pH10 and in green light, the best growth was observed on 15th day of incubation, as revealed by the number of cells and chlorophyll $a$ and $b$.

A five gram of $H$. pluvialis was extracted by preparative supercritical fluid chromatography. The total amount of extract was $210 \mathrm{ml}$, the fraction of astaxanthin detected at $6.403 \mathrm{~min}$, and the amount of $H$. pluvialis extracted from ethanol was $6.678 \mathrm{~min}$ (Table 5). The astaxanthin concentration in $H$. pluvialis extract was found to be $12.65 \mathrm{ml}^{-1}$ by SFC extraction and $126.89 \mathrm{mg} \mathrm{ml}^{-1}$ by ethanol extraction according to standard curve. Astaxanthin content in $H$. pluvialis was $0.53 \mathrm{mg} \mathrm{g}^{-1}$ by SFC extraction and 1.26 $\mathrm{mg} \mathrm{g}^{-1}$ by ethanol extraction method.
When astaxanthin was extracted from $H$. pluvialis, the yield was about $137 \%$ higher than SFC using $1.26 \mathrm{mg} \mathrm{g}^{-1}$ of ethanol. In addition to astaxathin, other substances lutein, canthaxanthin and $\beta$-carotene have also been analyzed (Beatriz et al., 2006). As a result of inhibition rate test, $I_{50}$ of astaxanthin standard reagent showed the highest antioxidative activity of 0.12 $\mathrm{mg} \mathrm{l}^{-1}, \mathrm{IC}_{50}$ of ascorbic acid was $14 \mathrm{mg} \mathrm{I}^{-1}$ and $H$. pluvialis was 48.09 $\mathrm{mgl}^{-1}$, respectively (Table 6).

Due to strong antioxidant activity, natural astaxanthin is recently increasing interest. However, the cost of production is still too expensive compared to synthetic products for commercial level. Because H. pluvialis have two main stage of life cycle, they have to increase the cell density at green stage and the content of astaxanthin at red stage. To increase biomass and astaxanthin, culture parameters such as medium composition, light source, $\mathrm{pH}$, temperature and predators should also be considered. Research have been conducted on a two-stage "perfusion culture" system which can be considered most efficient technology for high productivity, lower water consumption and less contamination (Park et al., 2014; Wan et al., 2014; Zhang et al., 2014). Whereas $\mathrm{pH}$ and light source can basically improve the yield of biomass and astaxanthin. Among $\mathrm{pH}$ values, biomass at $\mathrm{pH} 6$ was about 3 times higher than $\mathrm{pH} 8$ and 10 . Certain $\mathrm{pH}$ value 
also has the ability to inhibit bacterial growth, and Myhre et al., (1985) studied that bacterial growth inhibited below $\mathrm{pH} 7$. In the light source, green light showed $30 \%$ increased growth rate, and it is believed that the light source can improve the growth rate. Also, Tomohisa et al. (2004) resulted that culture of green light increased $\mathrm{H}$. pluvialis and astaxanthin content. Adjustment of $\mathrm{pH}$ value and light source are likely to be more economical alternatives than changes in culture system and genetic manipulation. Isolation of astaxanthin is expensive due to Low cell density and robust cell walls. For this, centrifugation, cell wall disruption by expeller pressing and bead milling are the most common technology for commercial scale. After cell walls disruption, other methods of astaxanthin extraction such as solvent, acids, edible oils, enzyme and supercritical carbon dioxide have been conducted in $H$. pluvialis, however, supercritical fluid extraction is increasingly used for industrial applications. Supercritical fluid is more efficient extraction fluid than traditional liquid solvents as well as ecofriendly (Machmudah et al., 2006). Modification of pressure and temperature, carbon dioxide act like liquid solvent. Efficient solvent extraction of astaxanthin from wet $H$. pluvialis biomass was achieved with liquefied dimethyl ether (Boonnoun et al., 2014) and also cell germination process in conjunction with ionic liquids treatment (Praveenkumar et al., 2015). There is a number of other areas of improvement that will contribute to the expansion of Haematococcus production capacity, lowering the production cost, extraction of astaxantnin and increasing market penetration at low end applications. Based on this study, it is expected to be basic data of economic and ecofriendly for accelerating the commercialization of astaxanthin.

\section{Acknowledgment}

This work was supported by the Soonchunhyang University.

\section{References}

Azov, Y. and J.C. Goldman: Free ammonia inhabition of algal photosynthesis in intensive cultures. Appl. Environ. Microbiol., 43, 735-73 (1982).

Beatriz, N., M. Filipa, P. Renata, B. Luis, P. Antonio, G. Luisa and M. Rui: Supercritical carbon dioxide extraction of astaxanthin and other carotenoids from the microalga Haematococcus pluvialis. Eur. Food Res. Technol., 223, 787-790 (2006).

Boonnoun, P., Y. Kurita, Y. Kamo, S. Machmudah, Y. Okita, E. Ohashi, E. Ohashi, H. Kanda and M. Goto: Wet extraction of lipids and astaxanthin from Haematococcus pluvialis by liquefied dimethyl ether. J. Nutr. Food Sci., 4, 305 (2014).

Chekanov, K., E. Lobakova, I. Selyakh, L. Semenova, R. Sidorov and A. Solovchenko: Accumulation of astaxanthin by a new Haematococcus pluvialis strain BM1 from the White Sea coastal rocks (Russia). Mar. drugs, 12, 4504-4520 (2014).

Dragoş, N., V. Bercea, A. Bica, B. Drugă, A. Nicoară and C. Coman: Astaxanthin production from a new strain of Haematococcus pluvialis grown in batch culture. Ann. Romani. Soc. Cell Biol.,15,
353-361 (2010).

Dong, S., Y. Huang, R. Zhang, S. Wang and Y. Liu: Four different methods comparison for extraction of astaxanthin from green alga Haematococcus pluvialis. Sci. World J., 2014, 1-8 (2014).

Harker, M., A.J. Tsavalos and A.J. Young: Factors responsible for astaxanthin formation in the chlorophyte Haematococcus pluvialis. Bioresour. Technol., 55, 207-214 (1996).

Han, D., Y. Li and Q. Hu: Astaxanthin in microalgae: Pathways, functions and biotechnological implications. Algae, 28, 131-147 (2013).

Helle, W., B.S. Anne and E.M. Karl: Antioxidant activity in extracts from coriander. Food Chem., 88, 293-297 (2004).

Jaime, L., I. Rodríguez-Meizoso, A. Cifuentes, S. Santoyo, S. Suarez, E. Ibáñez and F.J. Señorans: Pressurized liquids as an alternative process to antioxidant carotenoids' extraction from Haematococcus pluvialis microalgae. LWT-Food Sci. Technol., 43, 105-112 (2010).

Kang, C. A., M.R. Kim, J.Y. Shen, I.K. Cho, B.J. Park, I.S. Kim and J.H. Shim: Supercritical fluid extraction for liquid chromatographic determination of pyrazosulfuron-ethyl in soils. Bull. Environ. Contam. Toxicol., 76, 745-751 (2006).

Kang, C.D. and S.J. Sim: Direct extraction of astaxanthin from Haematococcus culture using vegetable oils. Biotechnol. Lett., 30, 441-444 (2008).

Krichnavaruk, S., A. Shotipruk, M. Goto and P. Pavasant: Supercritical carbon dioxide extraction of astaxanthin from Haematococcus pluvialis with vegetable oils as co-solvent. Bioresour. Technol., 99, 5556-5560 (2008).

Lee, M.Y., M.S. Yoo, Y.J. Whang, Y.J. Jin, M.H. Hong and Y.H. Pyo: Vitamin C, total polyphenol, flavonoid contents and antioxidant capacity of several fruit peels. Korean J. Food Sci. Technol., 44, 540-544 (2012).

Lorenz, R.T. and G.R. Cysewski: Commercial potential for Haematococcus microalgae as a natural source of astaxanthin. Trends Biotechnol., 18, 160-167 (2000).

Makio, K., K. Yoshiro, K. Toshihide, N. Naomichi and T. Yasunobum: Morphological changes in the life cycle of the green alga Haematococcus pluvialis. J. Ferment. Bioeng., 84, 94-97 (1997).

Machmudah, S., A. Shotipruk, M. Goto, M. Sasaki and T. Hirose: Extraction of astaxanthin from Haematococcus pluvialis using supercritical $\mathrm{CO}_{2}$ and ethanol as entrainer. Ind. Eng. Chem. Res., 45, 3652-3657 (2006).

Myhre, B.A., S.H. Demianew, R.N. Yoshimori, E.J. Nelson and R.A. Carmen: $\mathrm{pH}$ changes caused by bacterial growth in contaminated platelet concentrates. Ann. Clin. Lab. Sci., 15, 509-514 (1985).

Nobre, B., F. Marcelo, R. Passos, L. Beirão, A. Palavra, L. Gouveia and R. Mendes: Supercritical carbon dioxide extraction of astaxanthin and other carotenoids from the microalga Haematococcus pluvialis. Eur. Food Res. Technol., 223, 787-790 (2006).

Oh, S.J., D.I. Kim, T. Sajima, Y. Shimasaki, Y. Matsuyama, Y. Oshima, T. Honjo and H.S. Yang: Effects of irradiance of various wavelengths from light-emitting diodes on the growth of the harmful dinoflagellate Heterocapsacircularis quama and the diatom Skeletonema costatum. Fish. Sci., 74, 137-145 (2008).

Orosa, M., D. Franqueira, A. Cid and J. Abalde: Analysis and enhancement of astaxanthin accumulation in Haematococcus pluvialis. Bioresour. Techno., 96, 373-378 (2005).

Park, H.J., E.J. Jin, T.M. Jung, H. Joo and J.H. Lee: Optimal culture conditions for photosynthetic Microalgae Nannochloropsis oculta. Appl. Chem. Eng., 21, 659-663 (2010). 
Park, J.C., S.P. Choi, M.E. Hong and S.J. Sim: Enhanced astaxanthin production from microalga, Haematococcus pluvialis by two-stage perfusion culture with stepwise light irradiation. Bioprocess Biosyst. Eng., 37, 2039-2047 (2014).

Praveenkumar, R., K. Lee, J. Lee and Y. K. Oh: Breaking dormancy: An energy-efficient means of recovering astaxanthin from microalgae. Green Chem., 17, 1226-1234 (2015).

Renstrøm, B., G. Borch, O.M. Skulberg and S. Liaaen-Jensen: Optical purity of (3S, 3'S)-astaxanthin from Haematococcus pluvialis. Phytochemistry, 20, 2561-2564 (1981).

Sarada, R., R. Vidhyavathi, D. Usha and G.A. Ravishankar: An efficient method for extraction of astaxanthin from green alga Haematococcus pluvialis. J. Agric. food Chem., 54, 7585-7588 (2006).

Sukran, D., G. Tohit and S. Ridvan: Spectrophotometric determination of chlorophyll-A,B and total carotenoid contents of some algae species using different solvent. Turk. J. Bot., 22, 13-17 (1998).

Solovchenko, A.E.: Recent break throughs in the biology of astaxanthin accumulation by microalgal cell. Photosynth. Res., 125, 437-449 (2015).

Tomohisa, K., L. Abdolmajid, S. Kazumichi and K. Shingeo: Astaxanthin production by Haematococcus pluvialis under illumination with LEDs. Enz. Microbial. Technol., 35, 81-86 (2004).

Vänninen, I., D. M. Pinto, A. I. Nissinen, N. S. Johansen and L. Shipp: In:
1. Plant-ediated effects of artificial lighting on arthropods and tritrophic interactions. The Light of New Greenhouse Technologies. Ann. Appl. Biol., 157, 393-414 (2010).

Wallen, D. and G. Geen: Light quality in relation to growth, photosynthetic rates and carbon metabolism in two species of marine plankton algae. Mar. Biol., 10, 34-43 (1971).

Wan, M., J. Zhang, D. Hou, J. Fan, Y. Li, J. Huang and J. Wang: The effect of temperature on cell growth and astaxanthin accumulation of Haematococcus pluvialis during a light-dark cyclic cultivation. Bioresour. Technol., 167, 276-283 (2014).

Xiaoyan, Z., Z. Xiaowei, F. Lidan, Z. Haitao and Z. Bingwen: Effect of extraction and drying methods on antioxidant activity of astaxanthin from Haematococcus pluvialis. Food Bioprod. Process, 99, 197-203 (2016).

Zhekisheva, M., S. Boussiba, I.K. Goldberg, A. Zarka and Z. Cohen: Accumulation of oleic acid in Haematococcus pluvialis (chlorophyceae) under nitrogen starvation or high light is correlated with that of astaxanthin esters1. J. Phycol., 38, 325-331 (2002).

Zhang, W., J. Wang, J. Wang and T. Liu: Attached cultivation of Haematococcus pluvialis for astaxanthin production. Bioresour. Technol., 158, 329-335 (2014).

Zosel, K.: Process for recovering caffeine. US pat. No. 3.806 .619 (1974). 